\title{
Virtual Tourism In New Normal: Are People Going To Change Their Style Of Travel Temporarily Or Permanently?
}

\author{
Iswahyudi Iswahyudi ${ }^{1}$, Izmir Azlan ${ }^{2}$, Hafiz Azlan ${ }^{3}$ \\ \{iswahyudi.business@gmail.com¹, izmirazlan@gmail.com², hafizazlan@gmail.com\} \\ Faculty of Economics, Indonesia Open University ${ }^{1}$, Agency for ICT Accessibility, MCIT Indonesia ${ }^{2}$, \\ Faculty of Economics, Gunadarma University ${ }^{3}$
}

\begin{abstract}
In this Covid-19 pandemic 'new normal' era, Virtual Tourism could play a significant role in encouraging visitation and other tourism behaviors. Tourists' visit intention and VR users' continued use were determined by the hedonic motivation and technology acceptance model (TAM). However, there are limited studies on flow in virtual tourism. To address this gap, this study aims to examine the determinants affecting Visit Intention within Tourists in Indonesia. Empirical data from stay-at-home tourists during the pandemic who has been used VR application for the virtual tour were tested against the proposed research model by using structural equation modeling. The data was collected through an online survey involving 100 participants who have used and experienced virtual tourism during the pandemic. The results indicated that flow and continued use are the main factors affecting visit intention, whereas usefulness and enjoyment are the main factors affecting flow. The findings of this study provide several important implications for virtual tourism researches and practices.
\end{abstract}

Keywords: Flow, TAM, Visit intention, Virtual tourism

\section{Introduction}

Since it was declared as an outbreak [1] and pandemic [2], the novel Coronavirus (Covid-19) is challenging the world. Unprecedented travel restrictions and stay-at-home orders are causing the most severe disruption on the global economy, including tourism [3]. Many governments all over the world are taking severe measures to prevent and contain the spreading the virus, including Indonesia [4]. Despite significant growth over the year on tourism in Indonesia [5], this pandemic could decrease international tourists' arrival significantly [6].

On the other hand, Virtual reality (VR) is one of the most important topics in contemporary information management, given its increasing application in several industries [7-9], including tourism [10-15]. VR tourism is a virtual 
representation of an actual attraction, destination, or visitor experience that is designed as a prelude to visitation or to extend previous experiences of consumers [14]. While initially mainly formulated for management and marketing purposes [16].

Analyzing the effect of virtual reality (VR) tourism on the intention to visit has become an interesting topic in recent years $[10,12,15]$. Previous researches have utilized VR tourism user behavior using the technology acceptance model $[10,12,17]$, hedonic motivation $[13,14,18]$ and flow theory $[12,14,15]$ to understand tourists' experience on using 3D virtual world in tourism [17]. VR tourism is a visual depiction of real attractions, locations, or tourist interactions that are planned as a prelude to experiencing or expanding previous user experiences [14], providing necessary travel knowledge through destination experience representatives to persuade tourists to take action to visit tourist destinations [19-21].

Although VR technology has demonstrated its capabilities and is potential for a useful marketing tool [14], several studies show different research results related to this research framework that integrates technology acceptance model (TAM), hedonic motivation (i.e., enjoyment), and flow theory. The result [17] did not find that perceived ease of use could increase enjoyment, contradicted other findings $[9,12,18,22]$, the result of research [13] showed that perceived usefulness did not support flow experience, which was not in line with the study findings [12, 14, 23, 24]. Moreover, the results of research [14] show that perceived ease of use does not affect the flow state, contrary to other findings $[12,23,25]$. Therefore, this study will confirm those differences.

Furthermore, empirical studies have not adequately examined how the continued relationship between VR use will affect the intention of tourist visits to tourist destinations. Recent research [15] has utilized the relationship of affective response (i.e., enjoyment, emotional involvement, and flow state), attachment to VR, and visit intention. Kim and Hall [14] have tested the effect of flow state on subjective well-being and continued use. Lee [8] investigated through his research framework that VR satisfaction could affect intention to continue using VR and intention to visit a real destination. However, no research framework explains that the continued use of VR could directly influence the intention to visit. So far, there is a lack of empirical evidence for this argument.

In line with the prior considerations mentioned, to bridge the gap in the literature, this study examines the integration of the technology acceptance model (i.e., perceived ease of use, perceived usefulness), hedonic motivation (i.e., enjoyment), and flow theory in the context of virtual tourism. The purpose of this study was to determine which factors encourage potential tourists to visit tourist destinations displayed in VR, from the perspective of technology 
acceptance and hedonic motivation. Specifically, this study has three objectives: (1) to validate the effect of technology acceptance and hedonic motivation (i.e., enjoyment) on VR experiences related to tourism; (2) to examine the impact of the flow experience on continued use of VR and the intention of visiting tourist destinations; (3) to investigate the effect of continued use of VR in predicting visitation intentions of prospective tourists depicted in VR.

Consequently, this study contributes to the development and testing of theoretical models of TAM, hedonic motivation, and flow theory for the use of continuous VR and actual visits. Furthermore, the findings of this study may guide in developing useful promotional tools and market segmentation strategies for both parties, VR application developers, and tourism industry entrepreneurs.

\section{Literature review}

\subsection{Theoretical background}

\section{Virtual tourism}

Hobson and Williams [16] defined VR as an interactive digital-generated platform, enabling participants to explore virtual environments using a headmounted display (HMD) of a VR device. In the tourism industry, VR was used as a marketing tool to communicate with tourists by presenting information on destinations [12]. In recent years, the 3D virtual world has presented tourism destination promoters with the ability to interact with future travelers by providing an immersive interface that allows prospective tourists to look for tourism destinations [17]. VR offers the opportunity to create new interactions that could be of great value to heritage and environmental resources [26]. VR tourism offers potential tourists the chance to experience environments, journeys, sights, and special events from the comfort of their homes before choosing to visit [27].

VR has gained high interest from researchers and industries [28, 29]. Although VR has had a significant impact on tourism-related contexts, little understudies have been investigated that encourage VR tourists to visit the VR tourism destinations [15]. Hence, this study employs flow theory to resolve the gap in the literature by exploring the impact of technology acceptance model and hedonic motivation, which also influence continued use of VR tourism experiences and visit intention by prospective users who encounter VR tourism to the destinations seen in VR tourism activities. 


\section{Technology acceptance model (TAM)}

Davis [30] suggested TAM measure an individual's adoption of IT, postulating that perceived usefulness and perceived ease of use dictate an individual's attitude towards using IT. Perceived usefulness applies to the degree that individuals feel computer technology can allow them to serve their work better. Perceived ease of use applies to how a program is user-friendly, ensuring the efficiency gains are not overweighed by the implementation effort.

Mostly, numerous investigations have been carried out systematically with the implementation of a TAM leading to the adoption of IT by consumers [7, 9, $10,12,14,17,20,22,23,31]$. Many researchers have successfully used TAM to investigate the acceptance of technologies related to the Internet in many fields. In the field of information, technology, and tourism TAM has also gained substantial support from tourism researchers. Tourism study has commonly used the TAM to describe tourist behavior in VR [12, 14, 17], developed a hedonic motivation system adoption model (HMSAM) to highlight hedonic motivation systems for fun $[14,18]$. Despite the considerable impact of hedonic motivation systems on VR visitors, however, there is minimal VR tourism research on the continued use of customers, especially the enjoyment and flow state associated hedonic motivation [14]. This research advances the original TAM by combining perceived enjoyment as a variable of belief. Thus, this research considers providing a better understanding of the adoption of this technology by the tourist, indicating that perceived usefulness, perceived ease of use, and perceived enjoyment were major factors affecting the attitudes and intentions of the tourist to use VR in the decision-making process for the visit intention.

\section{Hedonic motivation system}

Systematic analysis of hedonics consumption, grounded in marketing literature, started in the 1970s [32, 33]. Hirschman and Holbrook [32] defined hedonic consumption as "those facets of consumer behavior that related to multisensory, fantasy and emotive aspects of product usage experience" and argued that the hedonic consumer viewpoint is not intended to replace traditional consumer ideas but to supplement them and expand our understanding of consumer behavior in marketing. They announced that hedonic consumer behavior involves emotional and creative reactions to goods.

A study of the literature indicates hedonic constructs of enjoyment [34, 35] are essential considerations for the interpretation of simulated reality in human 
and computer interaction studies [12]. Venkatesh [36] defined enjoyment in the computer-mediated environment as "the extent to which the activity of using a specific system is perceived to be enjoyed in its own right aside from any performance consequence resulting from system use." Researchers have customized the TAM to demonstrate how mainly intrinsic or hedonic motivation systems are adopted [14]. Lowry et al. [18] proving that flow as a full mediator is a strong and suitable determinant of intention to use VR. Kim and Hall [14] applied the flow state as a key mediator of VR tourism use. Based on the literature review, we expand HMSAM by adding flow state, continued use as a first target variable, visit intention as a second target variable, then link the two target variables to check a new context of user-related tourism VR. Consequently, this research uses HMSAM to classify consumer behaviour in the VR tourism domain.

\section{Flow theory}

The concept of flow was defined as "the holistic sensation that people feel when they act with total involvement [37]. Flow theory was one of the primary hedonic scientific constructs in the study of consumer behavior in technology usage $[11,35]$. Flow theory is a valuable resource for understanding the perspectives of individuals when exploring virtual worlds, and the flow condition was described as mediating the interaction between the participants and the future actions of VR tourists [38]. When entering a flow state, an individual becomes fully concentrated on their activity and experiences several positive experiential characteristics, including great pleasure and lack selfawareness [39]. In brief, flow experience suggests an emotional response selffeeling that a person gets, especially from a beneficial activity involvement/ interaction [40].

Siekpe [41] treats flow as a multidimensional construct, although its definitions and operationalizations differ considerably. In this study, the researcher treats flow as a first-order construct as has been used by previous researches [12-14, 22-25, 42, 43]. The benefit of virtual user flow state tourism study has not been concerned with understanding the optimum utilization of VR users, in particular the precedent of flow state integration in HMSAM [14]. Furthermore, this study chooses flow as the key determinant of continued use of VR and visit intention. 


\subsection{The Proposed Model}

The conceptual model that we propose is in line with the model developed by Kim and Hall [14] in which other consequences are incorporated into the model. Despite this, their study was not provided evidence of empirical research assessing the use of continuous VR for visit intention. The following hypotheses are presented based on the review of the literature in the preceding sections (see Fig. 1). Several previous studies have examined the impact of technology acceptance and hedonic motivation on VR user experience in the context of virtual tourism: perceived ease of use has a positive influence on perceived usefulness $(\mathrm{H} 1)$ [7, 9, 10, 17, 18, 23], and perceived enjoyment $(\mathrm{H} 2)[9,12,18$, 22]; perceived usefulness (H3) [12, 14, 23, 24], perceived ease of use (H4) [12, $23,25]$, perceived enjoyment $(\mathrm{H} 5)[13,14,18]$ has a positive effect on flow; flow has a positive impact on continued use (H6) [14, 22, 23, 42-45], and visit intention (H7) $[11,12,15,46]$. Then as a further analysis the researcher suspected that continued use has a positive effect on visit intention (H8).

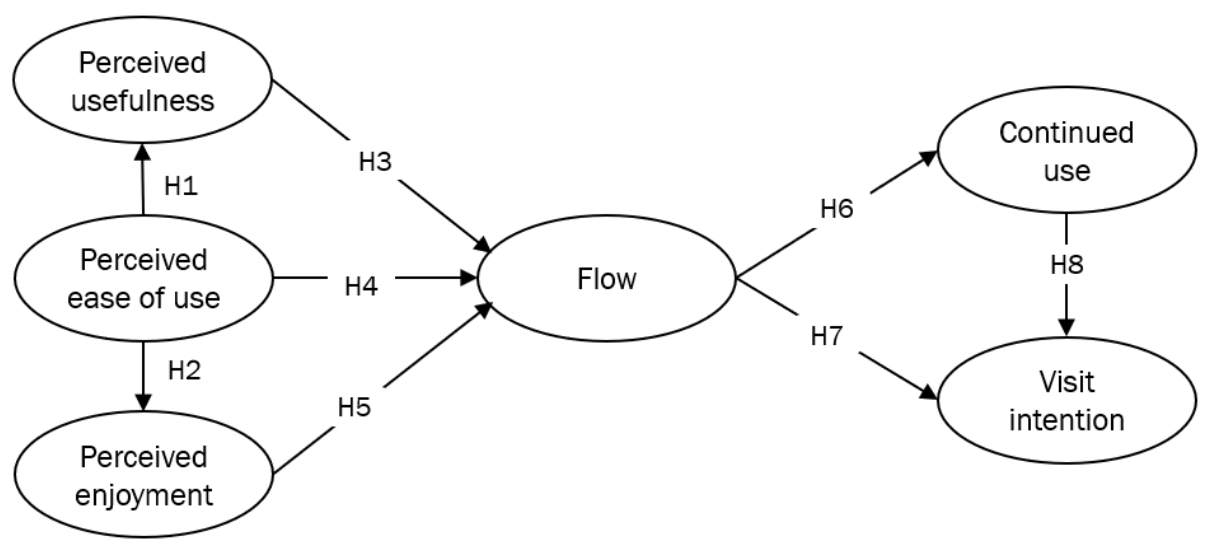

Fig. 1. The proposed research model

\section{Research Methods}

The study uses a quantitative approach methodology. The participants are virtual tourism users. They were involved in this study because it is directly related to the use of virtual tourism, so it can be ascertained that the research results are not biased. Study participants were asked to fill out the survey 
comfortably. The survey questionnaire was distributed online through the WhatsApp application to test hypotheses and to overcome research objectives. In this study, all measurement scales were adapted from previous studies, which are presented in Table 1. Data were analyzed using structural equation modeling (SEM) through partial least square (PLS) because PLS-SEM was built on techniques that did not assume that the data should be normally distributed [47].

Table 1. Measurement Scale

\begin{tabular}{|c|c|c|c|}
\hline Constructs & & Items & Sources \\
\hline \multirow[t]{4}{*}{$\begin{array}{l}\text { Perceived } \\
\text { ease of use }\end{array}$} & PEU1 & $\begin{array}{l}\text { It is easy for me to become skillful at using VR } \\
\text { application }\end{array}$ & {$[7,14]$} \\
\hline & PEU2 & Learning to operate VR application was easy for me & \\
\hline & PEU3 & $\begin{array}{l}\text { Using VR application for virtual tourism does nor } \\
\text { require a lot of mental effort }\end{array}$ & \\
\hline & PEU4 & Overall, I find it easy to use a VR application & \\
\hline \multirow[t]{4}{*}{$\begin{array}{l}\text { Perceived } \\
\text { usefulness }\end{array}$} & PU1 & $\begin{array}{l}\text { VR application for virtual tourism is useful for } \\
\text { collecting information }\end{array}$ & {$[14,48]$} \\
\hline & PU2 & $\begin{array}{l}\text { Using VR technology makes travel planning more } \\
\text { convenient }\end{array}$ & \\
\hline & PU3 & I find VR is useful for travel planning tasks & \\
\hline & PU4 & $\begin{array}{l}\text { VR technology would support me in planning for } \\
\text { future travels }\end{array}$ & \\
\hline \multirow{4}{*}{$\begin{array}{l}\text { Perceived } \\
\text { enjoyment }\end{array}$} & PE1 & I find VR application is very attractive to use & {$[12,14,48]$} \\
\hline & PE2 & $\begin{array}{l}\text { The actual process of using VR application is } \\
\text { pleasant }\end{array}$ & \\
\hline & PE3 & I have fun using VR application & \\
\hline & PE4 & $\begin{array}{l}\text { I thought experiencing in a } 3 \mathrm{D} \text { virtual world was } \\
\text { quite enjoyable }\end{array}$ & \\
\hline \multirow[t]{4}{*}{ Flow } & F1 & $\begin{array}{l}\text { When I am using VR application for a virtual tour, } \\
\text { time seems to pass very quickly }\end{array}$ & {$[12,14]$} \\
\hline & $\mathrm{F} 2$ & $\begin{array}{l}\text { When I am using VR application for a virtual tour, I } \\
\text { forget all concerns }\end{array}$ & \\
\hline & F3 & $\begin{array}{l}\text { Using VR application for virtual tour often makes } \\
\text { me forget where I am }\end{array}$ & \\
\hline & F4 & $\begin{array}{l}\text { When using VR application for a virtual tour, I feel } \\
\text { in control }\end{array}$ & \\
\hline \multirow[t]{2}{*}{$\begin{array}{l}\text { Continued } \\
\text { use }\end{array}$} & CU1 & $\begin{array}{l}\text { I will continue to use VR application for a virtual } \\
\text { tour in the future }\end{array}$ & {$[10,14]$} \\
\hline & CU2 & $\begin{array}{l}\text { I will update the VR application for a virtual tour in } \\
\text { the future }\end{array}$ & \\
\hline
\end{tabular}




\begin{tabular}{lcl}
\hline CU3 & $\begin{array}{l}\text { I will search for VR application for virtual tour in } \\
\text { the future } \\
\text { I predict I will use VR application for virtual tour in } \\
\text { the future }\end{array}$ \\
$\begin{array}{lcl}\text { Visit } \\
\text { intention }\end{array}$ & VI1 & $\begin{array}{l}\text { After the virtual tour, I will try to visit the place in } \\
\text { the future }\end{array}$ \\
VI2 & $\begin{array}{l}\text { After the virtual tour, I want to find out more } \\
\text { information about the place }\end{array}$ \\
VI3 & $\begin{array}{l}\text { I intend to visit the place frequently after } \\
\text { experiencing VR application for virtual tour } \\
\text { I will recommend the place others after experiencing } \\
\text { VR application for virtual tour }\end{array}$ \\
\hline
\end{tabular}

\section{Analysis and results}

\subsection{Sample characteristics}

The sample size $(n=100)$ varies hugely according to the characteristics of the respondent. The respondents (56\% male, $44 \%$ female) cover a wide variety of ages $(21-29,46 \% ; 30-39,35 \% ; 40-49,14 \% ;>50,5 \%)$. Certain categories are as follows: $21 \%$ of participants are employees, $17 \%$ are students, $14 \%$ are YouTubers (vloggers), and a few others. The majority using virtual reality based on smartphones $(51 \%)$.

\subsection{Validation of the measurement model}

Before analyzing the structural model, we must first measure the model. This is intended to test the reliability and validity of the indicators forming the latent constructs. PLS is very helpful because it has fewer restrictions on data normality and is ideal for model exploration and theory development $[49,50]$.

To test the convergent validity and reliability of the statement items, the value of the factor loadings was evaluated. Table 2 shows all loading measurements of the statement items, which were obtained from confirmatory factor analysis for each latent construct, with the recommended minimum threshold of $0.70[51,52]$, which shows the items the statement can meet the convergent validity value. There are still constructs that have an outer loading value $<0.7$, which is still acceptable for the construct development stage [53$55]$. 
Table 2. Results of confirmatory factor analysis

\begin{tabular}{|c|c|c|c|c|c|c|c|c|}
\hline Constructs & Items & Loadings & Mean & SD & $\mathrm{CR}$ & $\alpha$ & AVE & FVIF \\
\hline \multirow[t]{4}{*}{ Perceived ease of use } & PEU1 & 0.893 & 4.030 & 0.870 & 0.907 & 0.864 & 0.710 & 2.257 \\
\hline & PEU2 & 0.809 & 3.980 & 0.887 & & & & \\
\hline & PEU3 & 0.861 & 4.000 & 0.829 & & & & \\
\hline & PEU4 & 0.804 & 4.000 & 0.899 & & & & \\
\hline \multirow[t]{4}{*}{ Perceived usefulness } & PU1 & 0.765 & 4.070 & 0.795 & 0.860 & 0.783 & 0.606 & 2.486 \\
\hline & PU2 & 0.747 & 3.880 & 0.935 & & & & \\
\hline & PU3 & 0.833 & 3.890 & 0.952 & & & & \\
\hline & PU4 & 0.767 & 3.950 & 0.892 & & & & \\
\hline \multirow[t]{4}{*}{ Perceived enjoyment } & PE1 & 0.814 & 4.040 & 0.790 & 0.813 & 0.693 & 0.523 & 2.900 \\
\hline & PE2 & 0.708 & 4,070 & 0.728 & & & & \\
\hline & PE3 & 0.695 & 4.000 & 0.804 & & & & \\
\hline & PE4 & 0.668 & 3.900 & 0.893 & & & & \\
\hline \multirow[t]{4}{*}{ Flow } & $\mathrm{F} 1$ & 0.766 & 3.740 & 1.060 & 0.864 & 0.791 & 0.614 & 1.899 \\
\hline & F2 & 0.758 & 3.440 & 1.085 & & & & \\
\hline & F3 & 0.771 & 3.420 & 1.084 & & & & \\
\hline & F4 & 0.837 & 3.650 & 1.029 & & & & \\
\hline \multirow[t]{4}{*}{ Continued use } & CU1 & 0.813 & 4.020 & 0.910 & 0.865 & 0.794 & 0.616 & 2.709 \\
\hline & CU2 & 0.806 & 3.840 & 0.861 & & & & \\
\hline & CU3 & 0.805 & 3.940 & 0.874 & & & & \\
\hline & CU4 & 0.711 & 4.130 & 0.706 & & & & \\
\hline \multirow{4}{*}{ Visit intention } & VI1 & 0.691 & 4.040 & 0.706 & 0.834 & 0.739 & 0.559 & 2.451 \\
\hline & VI2 & 0.756 & 4.170 & 0.790 & & & & \\
\hline & VI3 & 0.838 & 3.620 & 1.126 & & & & \\
\hline & VI4 & 0.696 & 3.850 & 0.957 & & & & \\
\hline
\end{tabular}

The value of composite reliability and Cronbach's alpha are also measured to ensure measurement reliability. As shown in Table 2, five variables have composite reliability and Cronbach's alpha values that exceed the recommended threshold. Meanwhile, Cronbach's alpha for perceived enjoyment is still below 0.7 . But, the composite reliability value has been more than 0.7 so that researchers can ensure that all constructs meet the reliability of internal consistency [56, 57]. Furthermore, seeing the magnitude of the AVE value generated in each construct, which value is $>0.5$, this means that all constructs have met the criteria of convergent validity. Then the Full collinearity value of VIF in each construct also fulfills the rule of a thumb measurement model that is $<3.3$, which means that there is no multicollinearity problem between indicators. 
Furthermore, the latent construct (variable) in the study will also be tested for discriminant validity. Table 3 describes the discriminant validity of this study. The high value of discriminant validity provides evidence that a construct is unique and able to capture the phenomenon being measured.

Table 3. Latent variable correlations and square roots of AVEs

\begin{tabular}{lcccccc}
\hline & PEU & PU & PE & F & CU & VI \\
\hline Perceived ease of use (PEU) & 0.843 & & & & & \\
Perceived usefulness (PU) & 0.600 & 0.779 & & & & \\
Perceived enjoyment (PE) & 0.706 & 0.584 & 0.723 & & & \\
Flow (F) & 0.496 & 0.545 & 0.592 & 0.784 & & \\
Continued use (CU) & 0.610 & 0.650 & 0.712 & 0.637 & 0.785 & \\
Visit intention (VI) & 0.564 & 0.708 & 0.635 & 0.566 & 0.626 & 0.748 \\
\hline
\end{tabular}

\subsection{Assessment of the structural model}

Table 4 presents a summary of the fit indices data models that are often used in this type of analysis $[50,58]$. Four fit indices are shown, namely average path coefficients (APC), average R-squares (ARS), average full collinearity variance inflation factor (AFVIF), and Tenenhauss goodness-of-fit index (GoF). This compatibility index allows us to assess the extent to which the hypothesized model fits the data. The APC and ARS indices reveal problems related to structural models (relationships between related variables), while AFVIF and GoF are useful in identifying issues associated with measurement models (the relationship between latent variables and indicators).

Table 4. Model fit indices

\begin{tabular}{lll}
\hline Fit index & Value & Significance or acceptance level \\
\hline APC & 0.437 & $\mathrm{P}<0.001$ \\
ARS & 0.445 & $\mathrm{P}<0.001$ \\
AFVIF & 2.450 & Acceptable if $\leq 5$, ideally $\leq 3.3$ \\
GoF & 0.519 & Small $\geq 0.1$, medium $\geq 0.25$, large $\geq$ \\
& & 0.36 \\
\hline
\end{tabular}

APC was found to be statistically significant $(\mathrm{P}<0.001)$, as was ARS (P $<0.001)$. AFVIF is found with a result of 2,450 , which means it is below the threshold of the value 3.3, which indicates there is no wide collinearity in the model. The resulting GoF is at 0.519 above 0.360 , which means a large fit. Overall, this fits an index that suggests good model-data congruence, when considered together, and gives us confidence that hypothesis testing results are 
not significantly distorted by model misspecification bias. Table 5 summarizes whether or not there is support for the hypothesis.

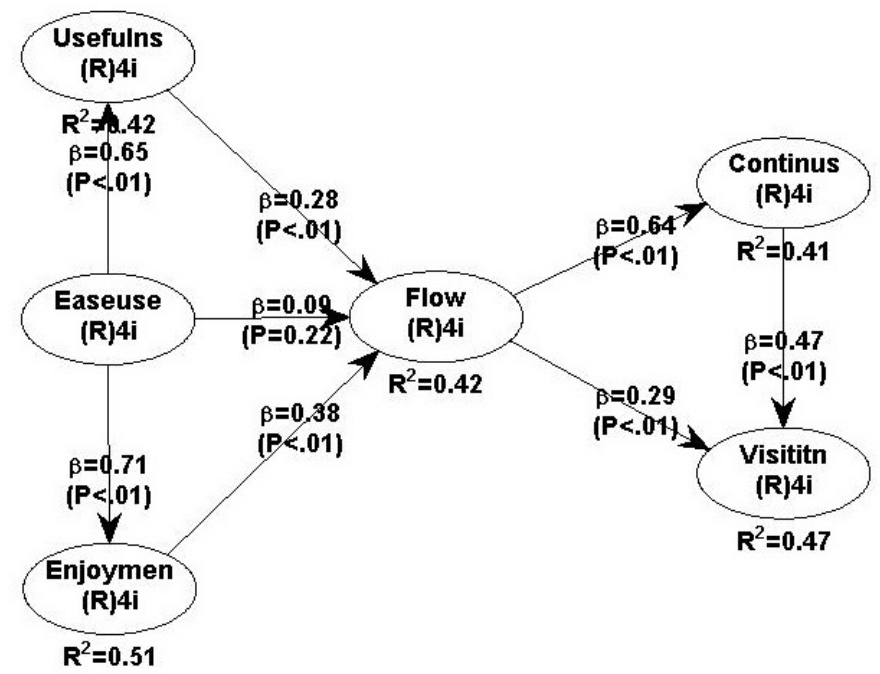

Fig. 2 Results of structural modeling

Based on Figure 2, perceived ease of use has a significant effect on perceived usefulness $(\beta=0.65, \mathrm{P}<0.001)$, is significant for perceived enjoyment $(\beta=0.71$, $\mathrm{P}<0.001)$, perceived usefulness has a significant effect on flow $(\beta=0.28, \mathrm{P}$ $<0.001)$, perceived enjoyment has a significant effect on flow $(\beta=0.38, \mathrm{P}$ $<0.001)$, but perceived ease of use has no statistical effect on flow $(\mathrm{P}=0.22)$, while flow has a strong effect on continued use $(\beta=0.64, \mathrm{P}<0.001)$, also has a significant effect on visit intention $(\beta=0.29, \mathrm{P}=0.002)$, an important finding in this study shows that continued use has a significant effect on visit intention $((\beta=0.47, \mathrm{P}<0.001)$. $)$, which means that the hypotheses H1, H2, H3, H5, H6, $\mathrm{H} 7$, and $\mathrm{H} 8$ are accepted, while the hypothesis $\mathrm{H} 4$ is rejected. The decision criterion (conclusion) is to look at the significance value of the P-value to determine the effect of the variables based on the hypothesis built through the resampling procedure. The significance value used was two-tailed with a $\mathrm{P}$ value of 0.05 (significance level $=5 \%$ ). The overall hypothesis test results are presented in Table 5. 
Table 5. Result of Hypotheses

\begin{tabular}{llllll}
\hline & & Path coefficient & P-value & T-value & Supported \\
\hline H1 & Easeuse $\rightarrow$ Usefulns & 0.652 & $<0.001$ & 11.177 & Yes \\
H2 & Easeuse $\rightarrow$ Enjoymen & 0.711 & $<0.001$ & 11.241 & Yes \\
H3 & Usefulns $\rightarrow$ Flow & 0.276 & $<0.001$ & 2.503 & Yes \\
H4 & Easeuse $\rightarrow$ Flow & 0.089 & 0.218 & 0.783 & No \\
H5 & Enjoymen $\rightarrow$ Flow & 0.375 & $<0.001$ & 2.890 & Yes \\
H6 & Flow $\rightarrow$ Continus & 0.639 & $<0.001$ & 9.234 & Yes \\
H7 & Flow $\rightarrow$ Visititn & 0.287 & 0.002 & 3.038 & Yes \\
H8 & Continus $\rightarrow$ Visititn & 0.467 & $<0.001$ & 4.122 & Yes \\
\hline
\end{tabular}

Notes: Easeuse $=$ perceived ease of use; Usefulns $=$ perceived usefulness; Enjoymen $=$ perceived enjoyment $;$ Continus $=$ continued use: Visititn $=$ visit intention

\section{Discussion}

As presented in the literature, this study has examined perceived ease of use, perceived usefulness, perceived enjoyment, flow, continued use, and visit intention in different virtual tourism contexts, in a pandemic situation. Therefore, this study seeks to examine the impact of factors from technology acceptance (perceived ease of use, perceived usefulness) and enjoyment on flow conditions and their impact on the continued use of virtual reality and the intention to travel. Towards this task, a series of hypotheses tests were carried out. As a result, the first hypothesis of this study predicts perceived ease of use for perceived usefulness. The ease of using VR is a recommendation as to the main factor in the usefulness of VR for users. H1 is accepted, this finding is in line with previous studies [7, 9, 10, 17, 18, 23].

The second hypothesis predicts the impact of perceived ease of use on perceived enjoyment. The higher the perceived level of ease of use, VR can create enjoyment for its users. These findings support previous studies [9, 12, 18, 22]. The third hypothesis yields a predictive finding of perceived usefulness for flow. Based on these findings, it means that the use of VR can create positive and memorable experiences. This finding is in line with previous studies [12, 14, 23, 24].

The fourth hypothesis was unable to predict perceived ease of use for flow, contrary to the hypothesized association. This may be that the perception of convenience does not necessarily create a memorable experience for VR users, this finding is in line with the results of Kim and Hall's [14] research.

The fifth hypothesis predicts the impact of perceived enjoyment on flow. The higher the level of pleasure of using VR can create a positive experience for its users. This finding supports previous studies [13, 14, 18]. 
The sixth hypothesis predicts the impact of flow on continued use. The higher the positive, memorable experience in using VR can encourage users to continue to use VR in the context of virtual tourism. These findings support previous studies [14, 22, 23, 42-45].

The seventh hypothesis predicts the impact of flow on visit intention. The higher the positive, memorable experience in using VR, it can encourage users to intend to visit tourist sites. These findings support previous studies [11, 12, 15, 46].

The eighth hypothesis is an important finding in this study because it has not been clearly tested by previous researchers. These findings predict the impact of continued use on visit intention. This is an insight into the context of virtual tourism, that users who continue to use VR have a higher intention of visiting tourist sites, as shown by the path coefficients and the P-value.

\section{Conclusions}

The main objective of the current study is to answer the question of whether VR tourism users will continue to use it or only temporarily during the pandemic. The study has found supportive results for both parties, in which the flow state of the VR user experience positively and significantly influences continued use VR and visit intention. The results help in the understanding of the behavior of virtual tourism engaged tourists. To date, research on tourism lacks any related studies to this one. Furthermore, this research expands our perception of virtual tourism and its pandemic-era visitors, in particular, Indonesia. It is setting the basis for potential virtual tourism studies.

The research results illustrate that people intend to continue the use of virtual tourism, besides that there is also a desire to visit tourist sites in the future. This means people will change their style, by finding out information and virtual experiences that when satisfied they will actually visit the tourist sites. These two ways may improve each other's business and experience.

From the perspective of the tourism industry, this study contributes to learning how best to create engaging and immersive tourism destinations in the virtual realm to attract both potential online and real-world tourists. Virtual tourism developers should strive to develop web-based and mobile applications that are useful for travel planning, which in turn can affect a tourist's behavioral intentions.

Though this research has produced some exciting results, the sampling procedure employed for an online survey in this study may be a limitation. We have, however, dedicated our efforts to simultaneously place the questionnaire 
on several larger online communities to cover a wider/larger variety of data sources for being more representative in the response sample.

Further research should involve a theory of planned behavior to understand the direct impact of using VR tourism, expanding the analysis to examine various factors in planning a tour, especially in this pandemic era. Together with a focus on recommendations for adherence to health protocols, this can help provide information to marketers, developers, companies, and local governments in making policies.

\section{References}

[1] World Health Organization. Statement on the second meeting of the International Health Regulations (2005) Emergency Committee regarding the outbreak of novel coronavirus (2019-nCoV). Geneva, Switzerland 2020; 1-6.

[2] World Health Organization. WHO Director-General's opening remarks at the media briefing on COVID-19 - 11 March 2020. WHO Director General's speeches 2020; 4.

[3] Gössling S, Scott D, Hall CM. Pandemics, tourism and global change: a rapid assessment of COVID-19. J Sustain Tour 2020; 0: 1-20.

[4] Presiden Republik Indonesia. Peraturan Pemerintah Nomor 21 Tahun 2020 tentang Pembatasan Sosial Berskala Besar Dalam Rangka Percepatan Penanganan Coronavirus Disease 2019/COVID-19. 21, Indonesia, 2020.

[5] UNWTO. International Tourism Highlights International tourism continues to outpace the global economy. Unwto 2019; 1-24.

[6] UNWTO. International Tourist Arrivals Could Fall By 20-30\% in 2020. Unwto.Org $2020 ; 33-34$.

[7] Syed-Abdul S, Malwade S, Nursetyo AA, et al. Virtual reality among the elderly: A usefulness and acceptance study from Taiwan. BMC Geriatr 2019; 19: 1-10.

[8] Lee W. Use of Immersive Virtual Technology in Consumer Retailing and Its Effects to Consumer. 2020; 2: 5-15.

[9] Manis KT, Choi D. The virtual reality hardware acceptance model (VR-HAM): Extending and individuating the technology acceptance model (TAM) for virtual reality hardware. J Bus Res 2019; 100: 503-513.

[10] Chung N, Han H, Joun Y. Tourists' intention to visit a destination: The role of augmented reality (AR) application for a heritage site. Comput Human Behav 2015; 50: $588-599$.

[11] Huang Y-C, Backman SJ, Backman KF. The Impacts of Virtual Experiences on People's Travel Intentions. Inf Commun Technol Tour 2010 2010; 555-566.

[12] Huang YC, Backman SJ, Backman KF, et al. Exploring user acceptance of 3D virtual worlds in travel and tourism marketing. Tour Manag 2013; 36: 490-501.

[13] Kim MJ, Lee CK, Bonn M. Obtaining a better understanding about travel-related purchase intentions among senior users of mobile social network sites. Int $J$ Inf Manage 2017; 37: 484-496.

[14] Kim MJ, Hall CM. A hedonic motivation model in virtual reality tourism: Comparing visitors and non-visitors. Int J Inf Manage 2019; 46: 236-249.

[15] Kim MJ, Lee CK, Jung T. Exploring Consumer Behavior in Virtual Reality Tourism 
Using an Extended Stimulus-Organism-Response Model. $J$ Travel Res 2020; 59: 6989.

[16] Williams P, Hobson JP. Virtual reality: A new horizon for the tourism industry. J Vacat Mark; 1995: 1 .

[17] Huang YC, Backman KF, Backman SJ, et al. Exploring the implications of virtual reality technology in tourism marketing: An integrated research framework. Int J Tour Res 2016; 18: 116-128.

[18] Lowry PB, Gaskin JE, Twyman NW, et al. Taking 'fun and games' seriously: Proposing the hedonic-motivation system adoption model (HMSAM). J Assoc Inf Syst 2013; 14: $617-671$.

[19] Gretzel U, Fesenmaier DR. Searching for the future: white paper on technology and change in destination marketing. Natl Lab Tour eCommerce, Univ Illinois UrbanaChampaign 2003.

[20] Cheng S, Cho V. An integrated model of employees' behavioral intention toward innovative information and communication technologies in travel agencies. J Hosp Tour Res 2011; 35: 488-510.

[21] Abou-Shouk M, Megicks P, Lim WM. Perceived benefits and e-commerce adoption by SME travel agents in developing countries: Evidence from Egypt. J Hosp Tour Res 2013; 37: 490-515.

[22] Lee M-C, Tsai T-R. What Drives People to Continue to Play Online Games? An Extension of Technology Model and Theory of Planned Behavior. Int J Hum Comput Interact 2010; 26: 601-620.

[23] Hsu CL, Yu CC, Wu CC. Exploring the continuance intention of social networking websites: An empirical research. Inf Syst E-bus Manag 2014; 12: 139-163.

[24] Wu IL, Chen KW, Chiu ML. Defining key drivers of online impulse purchasing: A perspective of both impulse shoppers and system users. Int J Inf Manage 2016; 36: 284 296.

[25] Chen W, Chen C. The Role of Utilitarian and Hedonic Values on Users' Continued Usage and Purchase Intention in a Social Commerce Environment. J Econ Manag 2017; 13: $193-220$.

[26] Chandler S. The Age Of Virtual Reality Tourism Is Fast Approaching. Forbes, 2020.

[27] Kinasz D. Virtual reality experiences becoming big part of tourism campaigns. Travelweek 2017.

[28] Jung T, tom Dieck MC, Lee H, et al. Effects of virtual reality and augmented reality on visitor experiences in museum. In: Information and communication technologies in tourism 2016. Springer, 2016, pp. 621-635.

[29] Tussyadiah IP, Wang D, Jung TH, et al. Virtual reality, presence, and attitude change: Empirical evidence from tourism. Tour Manag 2018; 66: 140-154.

[30] Davis FD. Perceived usefulness, perceived ease of use, and user acceptance of information technology. MIS Q Manag Inf Syst 1989; 13: 319-339.

[31] Kim TG, Lee JH, Law R. An empirical examination of the acceptance behaviour of hotel front office systems: An extended technology acceptance model. Tour Manag 2008; 29: 500-513.

[32] Hirschman EC, Holbrook MB. Hedonic consumption: emerging concepts, methods and propositions. J Mark 1982; 46: 92-101.

[33] Holbrook MB, Hirschman EC. The experiential aspects of consumption: Consumer fantasies, feelings, and fun. $J$ Consum Res 1982; 9: 132-140.

[34] Roca JC, Gagné M. Understanding e-learning continuance intention in the workplace: 
A self-determination theory perspective. Comput Human Behav 2008; 24: 1585-1604.

[35] Nah FF-H, Eschenbrenner B, DeWester D, et al. Impact of flow and brand equity in 3D virtual worlds. J Database Manag 2010; 21: 69-89.

[36] Venkatesh V. Determinants of perceived ease of use: Integrating control, intrinsic motivation, and emotion into the technology acceptance model. Inf Syst Res 2000; 11: 342-365.

[37] Csikszentmihalyi M. Beyond boredom and anxiety: The experience of play in work and leisure. San Fr CA: Jossey-Bass; 1975.

[38] Huang Y, Backman SJ, Backman KF. Exploring the impacts of involvement and flow experiences in Second Life on people's travel intentions. J Hosp Tour Technol 2012; 3: 4-23.

[39] Jackson SA, Marsh HW. Development and validation of a scale to measure optimal experience: The Flow State Scale. J Sport Exerc Psychol 1996; 18: 17-35.

[40] Horng SM, Lee YY, Wu CL. A study of the paying behavior for subscribing social network sites. Comput Commun 2016; 73: 282-290.

[41] Siekpe JS. An examination of the multidimensionality of flow construct in a computermediated environment. J Electron Commer Res 2005; 6: 31.

[42] Gao L, Waechter KA, Bai X. Understanding consumers' continuance intention towards mobile purchase: A theoretical framework and empirical study - A case of China. Comput Human Behav 2015; 53: 249-262.

[43] Landers VM, Beatty SE, Wang S, et al. The effect of online versus offline retailer-brand image incongruity on the flow experience. J Mark Theory Pract 2015; 23: 370-387.

[44] Li Z, Cheng Y. From free to fee: Exploring the antecedents of consumer intention to switch to paid online content. J Electron Commer Res 2014; 15: 281-299.

[45] van Noort G, Voorveld HAM, van Reijmersdal EA. Interactivity in Brand Web Sites: Cognitive, Affective, and Behavioral Responses Explained by Consumers' Online Flow Experience. J Interact Mark 2012; 26: 223-234.

[46] Kang JW, Lee H, Namkung Y. The impact of restaurant patrons' flow experience on SNS satisfaction and offline purchase intentions. Int J Contemp Hosp Manag 2018; 30: 797-816.

[47] Kock N. Non-normality propagation among latent variables and indicators in PLS-SEM simulations. J Mod Appl Stat Methods 2016; 15: 16.

[48] Disztinger P, Schl S, Groth A. Technology acceptance of virtual reality for travel planning. In: Schegg R, Stangl B, editor. Inf Commun Technol Tour 2017. Proceedings of the International Conference; January 24-26, 2017; Rome, Italy. Cham, Switzerland: Springer International Publishing; 2017. 255-268.

[49] Gefen D, Straub D. A practical guide to factorial validity using PLS-Graph: Tutorial and annotated example. Commun Assoc Inf Syst 2005; 16: 5.

[50] Moqbel M, Kock N. Unveiling the dark side of social networking sites: Personal and work-related consequences of social networking site addiction. Inf Manag 2018; 55: 109-119.

[51] Hair JF, Ringle CM, Sarstedt M. PLS-SEM: Indeed a silver bullet. J Mark theory Pract 2011; 19: 139-152.

[52] Kock N. WarpPLS user manual: Version 6.0. TX, USA: ScriptWarp Syst Laredo; 2017.

[53] Hulland J. Use of partial least squares (PLS) in strategic management research: A review of four recent studies. Strateg Manag J 1999; 20: 195-204.

[54] Hair JF, Sarstedt M, Ringle CM, et al. An assessment of the use of partial least squares structural equation modeling in marketing research. J Acad Mark Sci 2012; 40: 414- 
433.

[55] Hair JF, Ringle CM, Sarstedt M. Partial least squares structural equation modeling: Rigorous applications, better results and higher acceptance. Long Range Plann 2013; 46: $1-12$.

[56] Nunnally JC. Psychometric theory 3E. NewYork: Tata McGraw-Hill Education; 1994.

[57] Gefen D, Straub D, Boudreau M-C. Structural equation modeling and regression: Guidelines for research practice. Commun Assoc Inf Syst 2000; 4: 7.

[58] Chan DKC, Yang SX, Hamamura T, et al. In-lecture learning motivation predicts students' motivation, intention, and behaviour for after-lecture learning: Examining the trans-contextual model across universities from UK, China, and Pakistan. Motiv Emot 2015; 39: 908-925. 